Тамара САБЕЛЬНИКОВА

к. філол. наук, доцент, Донецький юридичний інститут

МВС України

\title{
ІДЕЯ РОДУ ЯК КОНЦЕПТ НАЦІОНАЛЬНОГО БУТТЯ УКРАЇНЦІВ (НА МАТЕРІАЛІ МІФОЛОГІЇ Й ФОЛЬКЛОРУ)
}

У статті на основі матеріалів української міфології й фольклору, а також звичаєвої обрядовості робиться спроба систематизувати традиційні уявлення наших предків про рід та родину, визначити місце родинних цінностей у сучасній культурі українців. Маючи витоки в дохристиянській традиції і пройшовши перевірку тисячолітнім досвідом, родинні цінності стали невід'ємною частиною сучасного світогляду нашого народу, що виявляється на ментальному рівні, і можуть претендувати на роль однієї з базових основ розбудови сучасного суспільства.

Ключові слова: рід, родина, дерево життя, дерево роду, культ предків, календарна та родинна обрядовість.

Світогляд народу, як відомо, формується впродовж багатьох тисячоліть його існування і виявляється на ментальному рівні. Світоглядно-духовні основи буття тієї чи іншої спільноти є їі генетичним кодом, об’єднавчим ядром i запорукою іiі незнищенності.

Сучасний німецький дослідник Ян Ассман наголошує, що кожна культура створює щось, що можна назвати ऑii ,„коннективною структурою”. Вона діє, з'єднуючи і пов'язуючи, причому у двох вимірах: соціальному та часовому. Як „символічний світ смислу”, вона пов’язує людину з її сучасниками, створюючи єдиний простір досвіду, очікувань і діяльності. Але вона пов’язує також учора й сьогодні, формуючи й утримуючи в живій пам’яті суттєві спогади й досвід. Цей аспект культури лежить в основі міфічних та історичних оповідей. Обидва аспекти: нормативний i наративний, аспект повчання й аспект оповіді створюють приналежність, або ідентичність, дозволяють окремій людині говорити „ми”. Те, що поєднує індивідів у таке „ми”, і є „коннективною структурою” спільного знання і уявлення про себе, яке спирається, по-перше, на підпорядкування спільним правилам та цінностям, а по-друге, на разом 
прожите минуле [1, 15-16]. Далі вчений зазначає, що суспільства, виробляючи культуру пам’яті про минуле, проносять свою ідентичність крізь зміну поколінь $[1,17]$. Однією зі сфер циркуляції культурного смислу він називає міфи, що забезпечують ідентичність [1, 22]. Дослідження в цій галузі завжди залишаються актуальними, зважаючи на значення їх результатів як певних орієнтирів у процесах розбудови суспільства та державотворення.

Основою, на якій зародилися нації, було родове буття. Тож, на нашу думку, саме родина з іï усталеними звичаями й традиціями, що формувалися впродовж багатьох тисячоліть, є одним із провідних концептів національного буття. Ідея роду, родини як частини світового порядку, освяченого богами, закладена в міфології, календарній та родинній обрядовості. Про це дізнаємося 3 досліджень О. Потебні [2], М. Грушевського [3], О. Воропая [4], С. Килимника [5], В. Войтовича [6], В. Жайворонка [7] та інших.

У цій статті ми поставили собі за мету, спираючись на дані міфології та фольклору, переважно обрядового (мусимо обмежитись, зважаючи на обсяг статті), систематизувати уявлення наших далеких предків про родину та рід, витоки яких сягають дохристиянської доби, i визначити їх місце в духовній культурі нашого народу.

На думку багатьох сучасних дослідників, одним із найважливіших богів слов’янського язичницького пантеону є Род - „творець Всесвіту, бог Життя, Долі, володар Вирію, батько Білобога і Чорнобога, опікун Дерева життя” [6, 423]. За давніми уявленнями наших предків, Род кидає на землю „груди”, тобто дощ, росу, і від того народжуються діти. Дружиною Роду є Земля-мати, якій він надає життєдайної сили [6, 423]. 3 плином часу від слова „Род” з’являються похідні - „родити”, „родитель”, „родильниця”, „рідний”, „родич” та інші. Розширюється й семантичне поле цього поняття. Слово „род” у стародавніх пам’ятках означає родичів, нащадків, земляків i навіть цілий народ, „який утворюється внаслідок народження" [6, 423]. Згодом згадуваний бог стає покровителем родини. 
Отже, початком життя на Землі, за уявленнями наших предків, є саме родина богів-прародителів Роду і Землі-матері, від яких пішли всі роди i, відповідно, увесь народ. Таким чином, родина, рід є однією із основоположних первин життя народу.

Ідея роду посідає особливе місце в духовності українців. До нинішніх часів у національній свідомості міцно закріпилося уявлення про зречення свого роду, відмову від нього як про найбільший гріх і сором. Родина і сьогодні для кожного українця - це традиційний символ душевного порятунку, затишку, ключова ланка родоводу, яка „постала від давнього родинного культу, що скріплював рід і беріг невгасний вогонь домашнього вогнища" [7, 504].

Уявлення про святість родини в ментальності українців закарбовано народними пареміями, які виступають кодом для розуміння норм співіснування і взаємодії людей та їхніх цінностей: „Нема в світі, як родина, то вам скаже і дитина” [8, 198]; „Принеси, Боже, здалека родину, то ми і в будень зробимо неділю" $[8,198]$. Незгода в родині або ії втрата сприймається як порушення світового порядку, руйнування космічної гармонії: „Хто батька-матір зневажає, той добра не знає” $[8,187] ;$ „Сироті без роду - хоч з мосту та в воду” $[8,197]$; „До свого роду хоч через воду” $[8,198]$.

Своєрідним актом продовження роду, забезпечення його невмирущості в народній традиції $є$ одруження, яке супроводжується весільним обрядом, сповненим сакральних дійств, спрямованих на вшанування родини як провідної ланки національного буття.

Важливим атрибутом весільного обряду є гільце, яке виступає символом бога Роду, прообразом райського дерева, що принесло колись першу прарідню. „Предки були переконані, що сам великий Род присутній тоді на весіллі 3 благословенням для молодої...” [6, 61]. Відповідно до обряду, молода просить благословення в батьків і всіх родичів, кланяючись кожному й цілуючи в руки й ноги та тричі цілуючись у губи $[6,60]$. 
Під час весілля відбувається об'єднання двох родів - молодого й молодої, символом якого виступає весільний коровай. Продукти для його виготовлення беруться від двох родин і змішуються в діжі, і дружки, вимішуючи його, співають: „Дівчина, як сонце, а козак, як місяць, а небо - дорога. Зійшлися два роди до милої згоди в ім'я Дажбога та й біля порога всі пообнімались, що кровно змішались - дітьми обмінялись" $[6,246]$.

Святість родини утверджується й обрядовими діями під час зимових календарних свят. Так, О. Потебня зазначає, що Різдво є переважно родинним святом, про що свідчить звичай їсти кутю у якнайповнішому сімейному колі, а також те, що діти носять кутю та узвар діду й бабі та хрещеним батькам [2, 148]. На ідеї об'єднання родини під час Різдвяних свят наголошує також і О. Воропай: „Заносячи вечерю, люди ніби намагаються приєднати живих членів роду до спільної, святвечірньої трапези" $[4,52]$.

Величання родини, яка уявлялась нашим предкам, за твердженням М. Грушевського, „як самозадоволена клітина - малий світ в собі” [3, 227], зустрічаємо в архаїчних зразках обрядового фольклору зимового циклу:

$$
\begin{aligned}
& \text { А в тім саду три тереми: } \\
& \text { У першому красне сонце, } \\
& \text { У другому ясен місяць, } \\
& \text { А в третьому дрібні зірки. } \\
& \text { Ясен місяць - пан господар, } \\
& \text { Красне сонце - жона його, } \\
& \text { Дрібні зірки - його дітки [9, 272-273]. }
\end{aligned}
$$

Астральні символи в щедрівці наділяють родину космічною гармонією Всесвіту, сакралізують іï і сповнюють міфологічного сенсу. Ідеалом відносин у родині, за народними уявленнями, є любов і взаємна повага. В одній із колядок звучать такі слова:

Хорошеньку господиню маєш,

Хорошенько її поважаєш:

Як чашечка у меду,

Як соловейко у саду. 
Там барвінок у саду процвітає,

Там чоловік жону вихваляє $[9,269]$.

Щастя в родині зображується звичними для фольклорної традиції символами: чашечка в меду викликає асоціації з солодким смаком, який постає символом щастя; у значенні народнопоетичного образу цвітіння завжди міститься відтінок свіжості, молодості, сили $[10,73]$, який посилюється згадкою про барвінок - вічнозелену рослину. Звичні просторово-пейзажні поняття та побутові деталі в пісенному контексті набувають емоційно-оцінного змісту й додаткових значень.

Вчені-народознавці неодноразово звертали увагу на особливе становище жінки-матері у традиційній українській сім’ї, на її провідну роль у повноцінних родинних стосунках. Це значною мірою пов'язано 3 міфологічними уявленнями, відповідно до яких Землю називали „святою і матір’ю, бо з неї створено першу людину, і вона годує всіх людей і тварин” [13, 286]. Пізніше поняття Землі-матері та матері в родині зливалися в одне ціле на основі подібності асоціацій $[14,85]$.

Про подружнє життя в українців писав свого часу В. Ізмайлов („Путешествіе въ полуденную Россію, въ письмахъ”. Москва, 1800), наголошуючи, що воно „відзначається великою любов’ю, пошаною і довірям” $[11,65]$.

Усталений космічний порядок родинного життя передається через символічний образ Дерева життя:

А в нашого пана - пана $\mathrm{N}$.

Стояла яблонь посеред двора,

На тій яблоні золота кора,

Золота кора - то його жона,

А що віточки - його донечки,

А що суче́чки - його синочки [3, 243].

Яблуня тут виступає прообразом дерева життя, яке складало основу анімістичного світогляду наших далеких пращурів: „Дерево життя - знамено трьох основ світу. Яв - світ видимий, явний, дійсний; стовбур Дерева життя - 
ISSN 2308-1902 Актуальні проблеми української літератури і фольклору. 2017. № 25.

то земне існування людей у просторі 3 Сонцем. Нав - світ невидимий, духовний, підземний, потойбічний, світ предків, коріння Дерева життя. Прав світ законів, правил, освячених звичаями, досвідом, обрядами; крона Дерева життя, де живуть боги, це їхній духовний світ" [6, 140]. Тож земне існування людини - лише частина світобудови, яка, з одного боку, тісно пов’язана зі світом предків, базується на ньому, а з іншого - підпорядковується звичаям і законам, сформованим життєвою практикою предків i наділена ними сакральним змістом.

Похідним від Дерева життя $є$ Дерево роду. Стародавній звичай зобов’язував кожного члена родини до набуття зрілості знати свій родовід до сьомого коліна $[6,143]$. Отже, рід складають не лише його живі члени, а й померлі, із якими зберігається постійний зв'язок, адже догмат про безсмертя душі споконвічно існував у індоєвропейському язичництві [2, 148]. Таким чином, культ предків став вагомою складовою суспільного життя нашого народу 3 давніх часів, що відображається в багатьох обрядах. Так, символом дерева роду виступає весільне гільце, яке стоїть на столі упродовж усього весілля, утверджуючи ідею вічності життя. Нове подружжя є проміжною ланкою між минулими й майбутніми поколіннями, а загалом усі вони складають єдину цілість, яка і $є$ родом. Предків закликають на весільний коровай: „Коровай росте-сходить, нову силу плодить, бабусі-дідусі близькі і далекі, з раю завітайте, внукам дари дайте, щоб множились роди багаті-завзяті” $[6,246]$.

Різдвяна Свята Вечеря, за уявленнями наших пращурів, $є$ спільною вечерею всього роду: як живих членів родини, так і померлих, які приходять у цей вечір до оселі, щоб зібратися з усім родом. Для померлих родичів у цей день ставили кутю та узвар на вікна, розкидали по кутках варений біб, залишали після вечері немиті ложки та миски, щоб, облизуючи їх, душі могли поживитися святковими стравами. Коли сідали, то спочатку продували місце, щоб не привалити собою якусь душу $[4,50]$. Під час цієї трапези приказували: 
„Святиї родителі, ходіть до нас хліба-солі істи”; „Їжте, пийте, вживайте і нас грішних споминайте" [3, 209]. Атрибутом Різдвяних свят є дідух - обжинковий або зажинковий сніп, виготовлений 3 житніх пучків, який також символізує Дерево роду [6, 143].

Культ предків $є$ важливим елементом багатьох календарних свят. Під час Великодніх урочистостей обов'язковим $є$ поминання померлих родичів на цвинтарі. О. Воропай, зокрема, так описує цей звичай: „..На могилах христосуються 3 померлими, котять по землі крашанки й кажуть: «Святі родителі, ходіте до нас хліба й соли з'їсти!» Потім сідають на могилі й закушують...” [4, 307].

Масове поминання померлих після Великодня називають Радуницею (варіанти - Радовниця, Родониця). Науковці пов'язують етимологію цього слова $з$ верховним богом Родом, а також із похідною від нього назвою родичі $[6,416 ; 7,493]$. Загальновідомим є той факт, що звичай поминати померлих після Великодня активно побутує і в сучасній Україні, незважаючи на те, що в радянські часи його відчайдушно намагалося викоренити партійне керівництво. За радянської влади цю традицію переважно підтримували селяни, зараз же вона активно відроджується по всій країні.

Як уже зазначалося, культ предків супроводжує багато календарних свят. Наступним періодом поминання померлих є Зелені Свята, які припадають на Трійцю. Саме в цей час починається квітування хлібних злаків. Щоб уберегти цвіт від лихого впливу злих сил, люди зверталися до мертвих предків, які вважалися охоронцями інтересів свого роду, по допомогу, поминали їх, приносили їм жертву, влаштовуючи тризни на гробках $[4,406]$.

Особливим днем поминання померлих восени $є$ Дмитрівська субота, або Дідів день чи осінні Діди. Вважалося, що „діди” приходили до своїх родин на поминальні обіди. На столи ставили їж, „щоб пара була” і „діди” могли іiі вдихати, і клали багато ложок, а також поминали кожного предка на ім'я [6, 154]. 
Таким чином, рід, родина включає як живих, так і померлих родичів, втілюючи модель світобудови у вигляді світового дерева, яке живлять його корені, що символізують світ предків. Тож кожна окрема родина - це мікрокосмос, у якому відображається життя Всесвіту 3 його космічним порядком.

Поховання на чужині сприймається особливо трагічно, бо це означає повне забуття, розрив родинних зв'язків, які зберігаються, як було проілюстровано, і після смерті:

Не дай, Боже, помирать,

То й нікому поховать.

Поховає чужина,

Не знатиме й родина,

Поховає чужий рід,

Не знатимуть, де мій слід $[12,68]$.

Коли рід живе у злагоді, це відповідає світовому порядку, космічній гармонії. Тому родичі почуваються щасливими, а гостина, на якій збирається весь рід, сповнюється особливої радості, що також знайшло своє відображення у фольклорній ліриці:

Ой зелене жито, зелене,

Хорошії гості у мене.

Зеленеє жито ще й овес,

[Ой] зібрався рід наш увесь $\}$ ?

(Зап. в 1995 р. в с. Донському Волноваського р-ну від Мовчан Олени Павлівни 1957 р. н.)

Образи злакових рослин (“жито”, “овес”), які символізують Боже благословення, добробут та родинне щастя $[15,70]$, надають пісні урочистого, радісного настрою, що найкраще відповідає ситуації. Пісня має амебейну структуру: перші два рядки кожної строфи залишаються незмінними, а наступні поступово нарощують почуття:

Зеленеє жито, зелене,

Хорошії гості у мене, 


\begin{abstract}
Зеленеє жито за селом,
Хорошії гості за столом.

Зеленеє жито, зелене,

Хорошії гості у мене,

Зеленеє жито женці жнуть,

Хорошії гості в мене п'ють.
\end{abstract}

(Зап. в 1996 р. в с. Антонівці Мар'їнського р-ну від Годунової Тетяни Миколаївни 1926 р. н.)

Гості-родичі характеризуються епітетом “хорошіі”, що двічі повторюється в кожній строфі. Таким чином підкреслюється радість ліричного героя від зустрічі 3 родом. Веселий настрій нарощується і змалюванням бенкету. Дієслово “п”ють” наділено конкретною семантикою: мається на увазі “п”ють хмільні напої”, що символізує веселощі $[2,14]$.

Підсумовуючи, зазначимо, що поняття „рід”, „родина” споконвіку мали сакральний характер у нашій національній ментальності. Це підтверджують давні міфологічні уявлення українців, їхні звичаї та традиції, пов'язані 3 календарною та родинною обрядовістю, а також численні фольклорні тексти. Давні уявлення міцно вкоренилися в національній свідомості і, як показує життєва практика, не втрачають актуальності в сучасному житті, гармонійно вписуючись у модерні реалії. Більше того, культивування родинних цінностей у сучасній культурі зміцнює духовні основи суспільства в цілому, сприяє його гуманізації та консолідації. Перспективою дослідження в цьому напрямі, на нашу думку, може бути тема родинних цінностей як основи національного буття в українській художній літературі, причому не лише у класичній, а і в сучасній, яка виявляє значний інтерес до цієї проблематики.

\title{
ЛІТЕРАТУРА
}

1. Ассман Ян. Культурная память: Письмо, память о прошлом и политическая идентичность в высоких культурах древности / Пер. с нем. М.М. Сокольской. М. : Языки славянской культуры, 2004. 368 с.

2. Потебня $A$. А. Символ и миф в народной культуре / Сост., подг. текстов, ст. и коммент. А.Л. Топоркова. М. : Лабиринт, 2000. 480 с.

3. Грушевський М. С. Історія української літератури: В 6 т. 9 кн. Т. 1/ Упоряд. В.В. Яременко; Авт. передм. П.П. Кононенко; Приміт. Л. Ф. Дунаєвської. К. : Либідь, 1993. 392 с. 
ISSN 2308-1902 Актуальні проблеми української літератури і фольклору. 2017. № 25.

4. Bоропай O. Звичаї нашого народу. Етнографічний нарис. К. : Акціонерне видавничо-поліграфічне товариство «Оберіг», 1993. 592 с.

5. Килимник $C$. Український рік у народних звичаях в історичному освітленні: [У 3 кн., 6 т.]. Факс. вид. К. : АТ «Обереги», 1994.

6. Войтович В. Українська міфологія. К. : Либідь, 2002. 664 с.

7. Жайворонок В. В. Знаки української етнокультури: Словник-довідник. К. : Довіра, 2006. $703 \mathrm{c}$.

8. Українські прислів'я та приказки. / Упоряд. С. Мишанича та М. Пазяка; Передм. М. Пазяка; Іл. худож. А. Василенка. К. : Дніпро, 1983. 390 с.

9. Календарно-обрядові пісні / Упоряд., передм., приміт. О. Ю. Чебанюк. К. : Дніпро, 1987. 392 с.

10. Єрмоленко С. Я. Нариси з української словесності: (стилістика та культура мови). К.: Довіра, 1999. $431 \mathrm{c.}$

11. Січинський В. Чужинці про Україну. Львів : Слово, 1991. 96 с.

12. Українські народні пісні в записах Михайла Стельмаха. К. : Музична Україна, 1969. $118 \mathrm{c}$.

13. Булашев $Г$. О. Український народ у своїх легендах, релігійних поглядах та віруваннях: Космогонічні українські народні погляди та вірування / Пер. 3 рос. Ю.Г. Буряка; Передм. В.О. Шевчука; Прим. О.М. Олійника. К. : Фірма «Довіра», 1993. 414 с.

14. Яременко $B$. Тарас Шевченко про святощі української родини. Народна творчість та етнографія. 1999. № 2-3. С. 80-92.

15. Костомаров Н. И. Об историческом значении русской народной поэзии // Костомаров М. І. Слов'янська міфологія: Вибрані праці з фольклористики й літературознавства. К. : Либідь, 1994. С. 44-200.

\section{REFERENCES}

1. Assman, Yan. (2004). Kulturnaya pamyat: Pismo, pamyat o proshlom i politicheskaya identichnost $v$ vyisokih kulturah drevnosti [Cultural memory: writing, memory about past and political identity in great cultures of antiquity]. Moskva: Yazyki slavianskoy kultury. [In Russian].

2. Potebnya, A. (2000). Symvol i mif v narodnoj culture [Symbol and myth in the folk culture]. Moskva: Labirint. [In Russian].

3. Grushevskyy, M. (1993). Istoria ukrayinskoyi literatury: V 6 t. $9 \mathrm{kn}$. [The history of the Ukrainian literature: In 6 volumes, 9 issues], Vol. 1. Kyiv: Lybid'. [In Ukrainian].

4. Voropay, O. (1993). Zvychayi nashogo narodu [Traditions of our folk]. Kyiv: Oberig. [In Ukrainian].

5. Kylymnyk, S. (1994). Ukrayinskyy rik u narodnyh zvychayah $v$ istorychnomu osvitlenni [U 3 kn., 6 vol.] [Ukrainian year in the national traditions in historical illustration] [In 3 issues, 6 vol.]. Kyiv: Oberegy. [In Ukrainian].

6. Voytovych, V. (2002). Ukrayinska mifologiya [The Ukrainian mythology]. Kyiv: Lybid'. [In Ukrainian].

7. Zhayvoronok, V. (2006). Znaky ukrayinskoyi etnokultury [The signs of the Ukrainian national culture]. Kyiv: Dovira. [In Ukrainian].

8. Myshanych, S., Paziak, M. (Eds.). (1983). Ukrayinski prysliv'ya ta prykazky [Ukrainian proverbs and sayings]. Kyiv: Dnipro. [In Ukrainian].

9. Chebaniuk, O. (Ed.). (1987). Kalendarno-obryadovi pisni [Calendar-ceremonial songs]. Kyiv: Dnipro. [In Ukrainian].

10. Yermolenko, S. (1999). Narysy z ukrayinskoyi slovesnosty (stylistyka ta kultura movy) [Essays on Ukrainian literature (Stylistics and culture of language)]. Kyiv: Dovira. [In Ukrainian]. 
11. Sichynskyy, V. (1991). Chuzhyntsi pro Ukrayinu [Foreigners about Ukraine]. Lviv: Slovo. [In Ukrainian].

12. Ukrayinski narodni pisni v zapysah Mykhayla Stelmakha [Ukrainian folk songs in Mykhaylo Stelmah's notes]. (1969). Kyiv: Muzychna Ukrayina. [In Ukrainian].

13. Bulashev, G. (1993). Ukrayinski narod u svoyih legendah, religiynyh poglyadah ta viruvannyah: Kosmogonichni ukrayinski narodni poglyady ta viruvannya [Ukrainian folk in its legends, religion views and believes: Cosmogonic Ukrainian folk views and believes]. Kyiv: Dovira. [In Ukrainian].

14. Yaremenko, V. (1999). Taras Shevchenko pro svyatoshchi ukrayinskoyi rodyny [Taras Shevchenko about sanctimony of Ukrainian family]. Folklore and Ethnography, 2-3, 80-92. [In Ukrainian].

15. Kostomarov, N. (1994). Ob istoricheskom znacheniyi russkoy narodnoy poeziyi [About historical importance of Russian folk poetry]. In M. Kostomarov, Slavik mythology (pp. 44-200). Kyiv: Lybid'. [In Russian].

\begin{abstract}
АННОТАЦИЯ
Тамара Сабельникова. Идея рода как концепт национального бытия украинцев (на материале мифологии и фольклора)

В статье на основе материалов украинской мифологии и фольклора, а также народных обрядов автор пытается систематизировать традиционные представления украинцев о роде и семье, определить место семейных ценностей в современной культуре украинцев. Уходя истоками в дохристианскую культуру и пройдя проверку тысячелетним опытом, семейные ценности являются неотъемлемой частью современного мировоззрения нашего народа, проявляющегося на ментальном уровне, и могут претендовать на роль одной из базовых основ построения современного общества.

Ключевые слова: род, семья, дерево жизни, дерево рода, культ предков, календарные и семейные обряды.
\end{abstract}

\title{
ABSTRACT \\ Tamara Sabelnykova. The idea of the kin as a concept of the national being of Ukrainians (based on mythology and folklore)
}

The primary aim of the article is, analyzing the data of mythology and folklore, mainly ritual genres of the least, to systematize the representation and the complicity of "family" and the "genus" concepts in structure of beliefs of our distant ancestors, whose origins reach the pagan age, and to determine their place in our people spiritual culture in forthcoming centuries. The place of family values in the modern Ukrainian culture was also determined during the study. It was concluded that primal idea of kin had been personalized in the person of "Rod", the first god of pagan Slavic pantheon. The image of ideal family had been inscribed in the myth about Rod and his wife goddess "Earth" (Earth-Mother). It is stated, according to previous researchers, that ideal of family, blessed weaving of two kins is obviously read through wedding ritual cycle. Honoring of ancestors, cult of dead family members is an important part of Ukrainian model of kin. Both proverbs and rituals had been strongly influenced with idea of integrity, immortality and continuity of kin. Lineage line, as pointed in the study, was metaphorically represented in the universal model of world Tree. Greeting of the dead kinfolk is traced through number of commemorative days of year holidays. Thus, it is summarized, the family values having origins in pre-Christian culture and passing the millennial experience, could be pointed as an integral part of the contemporary worldview of our people, which manifest itself at the mental level and may be qualified as one of the basic foundations for the development of modern society.

Key words: kin, family, tree of life, tree of the kin, cult of ancestors, calendar and family rituals.

Стаття надійшла до редакційної колегії 17.11.2017 року 